\title{
Relasi Tingkat Kepercayaan Khalayak Terhadap Pemberitaan di Media Massa dengan Budaya Membandingkan Informasi
}

\author{
Feri Ferdinan Alamsyah, Diana Amaliasari, Imani Satriani \\ Program Studi Ilmu Komunikasi - Fakultas Ilmu Sosial dan Ilmu Budaya (FISIB) \\ Universitas Pakuan - Jl. Pakuan PO Box 452 Bogor 16143 Jawa Barat Indonesia, Telepon : 0251- \\ 8338650,0251-8338650 \\ feriferdinan@gmail.com,d_amaliasari@yahoo.com, imani_satriani@yahoo.com,
}

\begin{abstract}
The purpose of this study was to find out the characteristics of students in the city of Bogor which is a mass media audience, and to know the relation between the level of audience trust in the news in the mass media and the culture of comparing information. This study uses descriptive quantitative correlational methods. The population in this study were students who enrolled in the city of Bogor, determining the sample using incidental sampling technique. The results showed that the characteristics of the mass media audience in this study were students who were dominated by women with a ratio of 61.2 percent with 38.8 percent. Generally they (61.9 percent) are between 19 and 21 years old. Their purchasing power or pocket money a month is worth Rp. 500,0001,000,000 with a total of 49.3 percent. Students who become respondents in this study are dominated by students from level 4 or students who study between the 7 th and 8th semesters, that is, 50 percent. They generally (69.4 percent) have a cumulative index (GPA) 4. In the essence of the news indicator with knowledge, attention, and interpretation there is a real and significant relationship with a positive direction. While indicators of communicators or news deliverers with knowledge, attention, and interpretation there is no relationship, meaning that respondents do not care about the identity of the source of information they receive. Indicators of the number of news with knowledge and interpretation there is a real and very significant relationship with the direction of the relationship that is in the same direction or positive. However, there is no relationship between the amount of news and student attention in the media coverage.
\end{abstract}

Keywords: audiences, compare information, mass media, media literacy

\begin{abstract}
Abstrak
Tujuan penelitian ini adalah mengetahui karakteristik mahasiswa di Kota Bogor yang merupakan khalayak media massa, dan mengetahui relasi tingkat kepercayaan khalayak terhadap pemberitaan di media massa dengan budaya membandingkan informasi. Penelitian ini menggunakan metode deskriptif kuantitatif korelasional. Populasi dalam penelitian ini adalah mahasiswa yang berkuliah di Kota Bogor, penentuan sampel menggunakan teknik incidental sampling. Hasil penelitian menunjukkan bahwa karakteristik khalayak media massa dalam penelitian ini adalah mahasiswa yang didominasi oleh kalangan perempuan dengan perbandingan 61,2 persen dengan 38,8 persen. Umumnya mereka (61,9 persen) berusia antara 19 hingga 21 tahun. Daya beli atau uang saku mereka perbulan rata-rata senilai Rp. 500.000-1.000.000 dengan jumlah 49,3 persen. Mahasiswa yang menjadi responden dalam penelitian ini didominasi oleh mahasiswa dari tingkat 4 atau mahasiswa yang berkuliah di antara semester 7 dan 8 , yakni sejumlah 50 persen. Mereka umumnya $(69,4$ persen) mempunyai indeks prestasi
\end{abstract}


kumulatif (IPK) 4. Pada indikator esensi berita dengan pengetahuan, perhatian, dan penafsiran terdapat hubungan yang nyata dan signifikan dengan arah yang positif. Sementara indikator Komunikator atau penyampai berita dengan pengetahuan, perhatian, dan penafsiran tidak terdapat hubungan, artinya responden tidak peduli dengan indentitas sumber informasi yang mereka terima. Indikator jumlah berita dengan pengetahuan dan penafsiran terdapat hubungan yang nyata dan sangat signifikan dengan arah hubungan yang searah atau positif. Namun, antara jumlah berita dengan perhatian mahasiswa dalam pemberitaan di media massa tidak terdapat hubungan.

Kata Kunci: khalayak, literasi media, media massa, membandingkan informasi

\section{Pendahuluan}

Musim pilpres terakhir pada 2014 lalu bisa menjadi salah satu contoh ketidakobjektifan media massa dalam pemberitaan. Aroma keberpihakan sangat terasa ketika TV One dan Metro TV memberitakan masing-masing calon presiden. TV One dinilai berpihak pada calon presiden Prabowo Subianto dan Hatta Radjasa, sementara Metro TV berpihak kepada calon presiden Joko Widodo dan Jusuf Kalla. Akibat keberpihakkan mereka, beberapa kali Komisi Penyiaran Indonesia (KPI) sempat melayangkan surat peringatan pemberian sanksi administratif teguran tertulis kepada kedua stasiun televisi tersebut. Selain itu, KPI juga memberikan rekomendasi kepada Kementerian Komunikasi dan Informatika (Kemenkominfo) untuk melakukan evaluasi atas Izin Penyelenggaraan Penyiaran (IPP). Diantaranya, teguran tertulis untuk TV One dan Metro TV itu bertanda No. 1225/K/KPI/05/14 yang dilayangkan pada 30 Mei 2014.

Media daring Tempo (2 Juni 2014) juga mengungkapkan pernyataan anggota KPI Iddy Muzzayad, berdasarkan pemantauan Komisi Pemilihan Umum (KPU) yang dilakukan pada 19-25 Mei 2014, Metro TV memberikan porsi yang lebih banyak kepada pasangan Capres Joko Widodo dan Jusuf Kalla yang totalnya mencapai 187 kali, angka ini jauh di atas tayangan pemberitaan pasangan Capres Prabowo dan Hatta Radjasa yang hanya 110 kali. Sebaliknya, TV One dalam periode ini, menampilkan pemberitaan pasangan Capres Prabowo dan Hatta Radjasa sebanyak 153 kali, sementara pasangan Capres Joko Widodo dan Jusuf Kalla muncul 79 kali.

Dari kasus tersebut, rasanya tidak berlebihan jika menyimpulkan bahwa media massa, khususnya di Indonesia secara tidak langsung telah berpihak kepada kepentingan tertentu. Meskipun tetap menampilkan fakta dan data yang benar dari setiap informasi yang diberitakan, namun pemilihan porsi dan jumlah berita yang terkesan memihak pada kepentingan tertentu membuat media massa sudah tidak objektif lagi.

Jumat, 4 November 2016, ratusan ribu umat Islam dari sejumlah daerah berkumpul di Jakarta untuk melakukan tuntutan yang sama, yakni menuntut polisi agar secepatnya menindaklanjuti laporan dugaan penistaan agama dengan terduga Ahok. Dari contoh tersebut, maka bisa disimpulkan bahwa penyebaran informasi di media massa dan media sosial memberikan dampak yang luar biasa. Pemilihan fakta yang dilakukan oleh pembuat informasi dengan cepat mampu memengaruhi 
Feri Ferdinan Alamsyah, Diana Amaliasari, Imani Satriani : Relasi Tingkat Kepercayaan Khalayak Terhadap Pemberitaan di Media Massa dengan Budaya Membandingkan Informasi

persepsi khalayak dalam mengambil keputusan untuk bertindak. McQuail (2012) menyebut ini adalah efek media massa yang terjadi dalam waktu pendek, secara cepat, instan dan keras memengaruhi seseorang atau masyarakat

Dari realitas di atas, bisa disimpulkan bahwa media massa mempunyai daya besar yang bisa memengaruhi khalayaknya. Padahal, di sisi lain, informasi yang di sampaikan media massa tidak jarang bertentangan atau bias dengan pemahaman yang ada pada khalayak. (Carrascosa, Cuevas, Gonzalez, Azcorra dan Garcia, 2015)

Besarnya pengaruh dari penyebaran informasi di media massa bagi khalayaknya, membuat khalayak seyogyanya terbiasa melakukan literasi media. Dalam konsep literasi media, budaya bermedia yang baik salah satunya adalah membandingkan informasi yang disampaikan oleh media massa.

Melalui membandingkan informasi, tujuannya agar khalayak mengambil tindakan atau memutuskan sesuatu ketika dia merespon informasi dari media massa, dilandasi pada pemikiran yang komprehensif. Jika khalayak melakukan perbandingan informasi tersebut, artinya khalayak telah mendapatkan sebuah informasi dari banyak media massa dengan perspektif yang beragam, dengan demikian, khalayak mempunyai gambaran utuh mengenai informasi yang ia terima tersebut. Oleh sebab itu, khalayak akan dapat menilai kebenaran informasi dan kredibilitas penyampai informasi dahulu sebelum memutuskan untuk mengambil tindakan tertentu. Misalnya apakah mereka akan setuju atau tidak setuju dengan konten pemberitaan yang disampaikan oleh media massa.

Sari (2018) menjelaskan pemilihan media sebagai sumber informasi menjadi penting agar masyarakat atau khalayak tidak melakukan keputusan sepihak tanpa melihat utuh realitasnya. Ia mencontohkan pada diskriminasi atas jemaah Ahmadiyah, media Kompas Online yang melalui pemberitaannya menyediakan informasi bahwa telah terjadi diskriminasi terhadap kelompok atau jemaah Ahmadiyah. Dengan pemlihan media yang tepat, diharapkan masyarakat Indonesia menjadi sadar akan adanya tindak diskriminasi dan dapat bersikap secara kritis dalam menghadapinya.

Sejalan dengan konsep tersebut, Pemerintah melalui tangan Komisi Penyiaran Indonesa (KPI) selalu menanamkan budaya media literasi pada khalayak media massa pada umumnya agar tidak mudah terpengaruh oleh efek negatif yang ditimbulkan.

Penelitian ini ingin melihat sejauh mana khalayak mempunyai tingkat kepercayaan terhadap pemberitaan di media massa melalui kebiasaan membandingkan informasi yang ditampilkan di setiap media massa dan media sosial yang mereka akses. Sejauh mana mereka mempunyai kebiasaan membandingkan informasi yang disampaikan media massa dan media sosial. Serta melihat bagaimana hubungan kegiatan membandingkan informasi dengan tingkat kepercayaan khalayak terhadap media massa sebagai sumber penyampai pesan. Oleh sebab itu, maka masalah dalam penelitian ini akan dirumuskan sebagai berikut: (1) Bagaimana deskripsi karakteristik mahasiswa di Kota Bogor yang merupakan khalayak media massa? ; (2) Bagaimana relasi tingkat kepercayaan khalayak terhadap pemberitaan di media massa dengan budaya membandingkan informasi? 


\section{Metode Penelitian}

Penelitian ini berusaha menjelaskan dan menguraikan fenomena yang diteliti menggunakan metode kuantitatif dengan desain penelitian survey yang bersifat deskriptif korelasional. Pengamatan dalam penelitian ini diharapkan mampu menjelaskan persepsi mahasiswa terhadap penayangan sidang di televisi, serta menguji hubungan antara dua variabel. Variabel pertama dalam penelitian ini adalah karakteristik Mahasiswa yang berkuliah di Universitas kota Bogor dan budaya membandingkan informasi yang ada pada mereka. Variabel ke dua adalah tingkat kepercayaan khalayak terhadap pemberitaan di media massa. Tingkat kepercayaan ini akan diketahui berdasarkan pada aspek pengetahuan, perhatian dan penafsiran.

Populasi adalah wilayah generalisasi yang terdiri atas objek/subjek yang mempunyai kualitas dan karakteristik tertentu yang ditetapkan oleh peneliti untuk dipelajari dan kemudian ditarik kesimpulannya, (Sugiyono, 2016). Berdasar pada keterangan tersebut maka populasi dalam penelitian ini adalah Mahasiswa yang yang berkuliah di Universitas yang ada di kota Bogor.

Berdasarkan data dari Kementerian Riset, Teknologi dan Pendidikan Tinggi (Kemenristekdikti), jumlah mahasiswa yang berkuliah di universitas yang berlokasi di Kota Bogor jumlahnya sebanyak 20.148 mahasiswa. Jumlah tersebut terdiri dari 11.802 mahasiswa aktif berkuliah di Universitas Pakuan, 3.556 di Universitas Djuanda, 382 mahasiswa di Universitas Nusa Bangsa dan 4.408 Mahasiswa di Universitas Ibnu Khaldun (www.forlap.dikti.go.id- diakses 11 November 2016)

Sampel adalah bagian dari jumlah dan karakteristik yang dimiliki oleh populasi tersebut. Apa yang dipelajari dari sampel tersebut, kesimpulannya dapat berlaku juga untuk populasinya. Untuk itu, menurut Sugiyono (2016) sampel yang diambil dari populasi harus betul-betul presentatif. Penentuan ukuran sampel dalam penelitian ini berdasarkan rumus slovin dengan tujuan untuk mendapatkan sampel yang lebih pasti atau mendekati populasi yang ada. Seperti berikut:

$$
n=\frac{N}{1+N e 2}
$$

Keterangan:

$$
\begin{aligned}
n & =\text { Ukuran sampel } \\
\mathrm{N} & =\text { Ukuran populasi } \\
\mathrm{E} & =\text { Tingkat kesalahan yang ditolelir dalam pengambilan sampel, } \\
& \text { tingkat kesalahan } 10 \%(\alpha)
\end{aligned}
$$

Hasil perhitungan dalam penentuan sampel minimal dengan jumlah populasi rata-rata Mahasiswa yang berkuliah di Universitas Kota Bogor, dengan menetapkan presisi sebesar $10 \%(0,1)$ adalah sebagai berikut:

$$
\begin{aligned}
n & =\frac{20.148}{1+20.148(0,1)^{2}} \\
& =99,506
\end{aligned}
$$


Berdasarkan perhitungan tersebut, maka jumlah sampel dalam penelitian ini adalah sebanyak 99,506 atau dibulatkan menjadi 100 orang. Teknik penentuan sampel dalam penelitian ini dilakukan dua tahap, pertama menggunakan teknik stratified random sampling diikuti dengan incidental sampling. Incidental sampling, yaitu teknik penentuan sampel secara kebetulan, yaitu siapa saja secara kebetulan/insidental bertemu dengan peneliti dapat digunakan sebagai sampel, bila dipandang orang yang kebetulan ditemui itu cocok sebagai sumber data (Sugiyono, 2016).

Teknik pengambilan sampel tahap kedua yang digunakan yaitu stratified random sampling. Sampel ini bertujuan untuk membuat sifat homogen dari populasi yang heterogen, artinya suatu populasi yang dianggap heterogen dikelompokkan ke dalam subpopulasi berdasarkan karakteristik tertentu sehingga setiap kelompok (strata) mempunyai anggota sampel yang relatif homogen (Kriyantono, 2012). Adapun cara yang digunakan untuk mengetahui jumlah sampel secara proposional dalam tiap subpopulasinya sebagai berikut:

$$
\begin{aligned}
& \text { Sampel }=\frac{\text { Populasi }}{\text { Total populasi }} \times \text { Total Sampel } \\
& \text { Universitas Pakuan } \quad=\frac{11.802}{20.148} \times 100=58,57=58 \text { mahasiswa } \\
& \text { Universitas Djuanda } \quad=\frac{3.556}{20.148} \times 100=17,64=18 \text { mahasiswa } \\
& \text { Universitas Nusa Bangsa }=\frac{382}{20.148} \times 100=1,89=2 \text { mahasiswa } \\
& \text { Universitas Ibnu Khaldun }=\frac{4.408}{20.148} \times 100=21,87=22 \text { mahasiswa }
\end{aligned}
$$

Teknik analisis data yang digunakan dalam penelitian ini adalah teknik analisis statistik inferensial. Statistik inferensial adalah teknik statistik yang digunakan untuk menganalisis data sampel dan hasilnya diberlakukan untuk populasi (Sugiyono, 2016). Uji koefesien dan korelasi rank spearman untuk data terendah dengan skala ordinal dengan rumus sebagai berikut: 


$$
r_{S}=1-\frac{6 \sum d i^{2}}{n\left(n^{2}-1\right)}
$$

Keterangan:

$r_{s} \quad=$ Koefesien koelasi rank spearman

$d i=$ Beda antara dua peubah berpasangan

1 dan 6 = Bilangan koefesien

Sedangkan teknik analisis data yang digunakan untuk menganalisis data terendah dengan skala nominal dalam penelitian ini menggunakan chi-square dengan rumus sebagai berikut:

$$
X^{2}=\sum \frac{\left(f_{0}-f_{e}\right)^{2}}{f_{e}}
$$

Keterangan:

$X^{2} \quad=$ Chi kuadrat

$f_{0} \quad=$ Frekuensi yang diobservasi

$f_{e} \quad=$ Frekuensi yang diharapkan

Penelitian ini menggunakan skala Likert sebagai skala pengukuran pernyataan dari persepsi Mahasiswa. Menurut Sugiyono (2016) skala Likert digunakan untuk mengukur sikap, pendapat dan persepsi seseorang atau sekelompok orang tentang fenomena sosial. Indikatornya terdapat pada tabel berikut:

Tabel 1. Pengukuran Sikap Berdasarkan Skala Likert

\begin{tabular}{l|c}
\hline \multicolumn{1}{c|}{ Pendapat } & Skor \\
\hline Sangat Setuju & 4 \\
Setuju & 3 \\
Tidak Setuju & 2 \\
Sangat tidak setuju & 1 \\
\hline
\end{tabular}


Feri Ferdinan Alamsyah, Diana Amaliasari, Imani Satriani : Relasi Tingkat Kepercayaan Khalayak Terhadap Pemberitaan di Media Massa dengan Budaya Membandingkan Informasi

\section{Hasil Penemuan dan Diskusi}

Tabel 2. Nilai Uji Korelasi antara Membandingkan Media dengan Tingkat Kepercayaan Khalayak terhadap Pemberitaan di Media Massa

\begin{tabular}{lllll}
\hline \multirow{2}{*}{$\begin{array}{l}\text { Membandingkan } \\
\text { Media (X2) }\end{array}$} & Uji Korelasi & \multicolumn{3}{c}{ Tingkat Kepercayaan Khalayak (Y) } \\
& Rank Spearman & Pengetahuan & Perhatian & n \\
\hline \multirow{2}{*}{ Essensi Berita } & Correlation & & & \\
& Coefficient & $\mathbf{. 2 8 6 * *}$ & $\mathbf{. 1 9 5} *$ & $\mathbf{. 0 3} *$ \\
& Sig. (2-tailed) & 0.001 & 0.024 & 0.019 \\
& $\mathrm{~N}$ & 134 & 134 & 134 \\
\hline \multirow{3}{*}{ Komunikator } & Correlation & & & \\
& Coefficient & $\mathbf{0 . 1 4 3}$ & $\mathbf{0 . 1 2 1}$ & $\mathbf{0 . 1 4 3}$ \\
& Sig. (2-tailed) & 0.098 & 0.165 & 0.1 \\
& $\mathrm{~N}$ & 134 & 134 & 134 \\
\hline \multirow{3}{*}{ Jumlah Berita } & Correlation & & & \\
& Coefficient & $\mathbf{. 2 3 5 * *}$ & $\mathbf{0 . 0 9 1}$ & $\mathbf{. 1 8 2}$ \\
& Sig. (2-tailed) & 0.006 & 0.295 & 0.036 \\
& $\mathrm{~N}$ & 134 & 134 & 134 \\
\hline
\end{tabular}

* Correlation is significant at the 0.05 level (2-tailed).

** Correlation is significant at the 0.01 level (2-tailed).

Sumber: Data Primer 2018

Hasil penelitian mengenai hubungan antara variabel membandingkan berita dengan variabel tingkat kepercayaan khalayak terhadap pemberitaan di media massa dapat dilihat pada tabel 2, dari tabel tersebut memperlihatkan hasil korelasi antara Variabel X2 yang memiliki indikator esensi berita, komunikator, dan jumlah berita, dengan Variabel $\mathrm{Y}$ yang memiliki indikator pengetahuan, perhatian dan penafsiran, keseluruhan korelasi menggunakan analisis rank spearman untuk melihat nilai hubungan, signifikansi dan arah hubungan. Adapun nilai korelasi antara membandingkan media pada esensi berita dengan tingkat kepercayaan khalayak pada indikator pengetahuan sebesar 0.286 dengan nilai signifikansi sebesar 0.001, dari nilai koefisien korelasi dan signifikansi tersebut maka dikatakan bahwa terdapat hubungan yang nyata dan sangat signifikan antara esensi berita dengan pengetahuan dengan arah hubungan yang positif atau searah. Sehingga apabila nilai esensi berita yang ada pada media massa semakin baik maka akan semakin tinggi pengetahuan yang didapat oleh mahasiswa sehingga semakin percaya mereka (mahasiswa) pada isi dari pemberitaan yang ada pada media massa yang mereka baca.

Sama halnya dengan hasil korelasi antara esensi berita dan perhatian dengan nilai koefisien korelasi sebesar 0.0195 dan nilai signifikansi sebesar 0.024, maka dari data tersebut didapatkan adanya hubungan yang nyata dan signifikan antara nilai esensi berita dengan perhatian mahasiswa terhadap pemberitaan di media massa dengan arah hubungan yang positif atau searah. Oleh karena itu dapat ditarik kesimpulan bahwa apabila nilai esensi dari berita semakin 
berkualitas maka mahasiswa akan semakin besar perhatiannya terhadap pemberitaan yang ada di media massa sehingga menyebabkan semakin meningkat kepercayaan mahasiswa. Oleh sebab itu apabila media massa ingin menarik perhatian mahasiswa dan ingin mendapatkan kepercayaan dari mahasiswa maka media massa tersebut harus selalu memperbaiki nilai esensi berita yang diberitakan di media massanya.

Korelasi antara esensi berita dengan penafsiran mahasiswa terhadap pemberitaan di media massa memiliki nilai koefisien korelasi sebesar 0.203 dengan nilai signifikansi sebesar 0.019, dari besaran nilai tersebut dapat dikatakan bahwa terdapat hubungan yang nyata dan signifikan antara indikator esensi berita dengan penafsiran mahasiswa dengan arah hubungan yang positif atau searah, sehingga dapat ditarik kesimpulan dari kedua hubungan tersebut apabila nilai esensi berita semakin diperhatikan dan semakin baik isinya maka akan semakin baik pula penafsiran mahasiswa pada pemberitaan di media massa. Ketika mahasiswa membandingkan media yang dibacanya atau diaksesnya, apabila ia menilai esensi berita yang dimuat tersebut baik dan bermanfaat maka penafsiran mahasiswa terhadap pemberitaan pada media massa tersebut akan semakin baik pula.

Beralih ke indikator komunikator atau penyampai berita, pada indikator komunikator akan dilihat hubungannya dengan indikator $\mathrm{Y}$ yaitu Pengetahuan, perhatian dan penafsiran. Pertama akan dibahas hubungan antara komunikator yaitu penyampai berita dengan pengetahuan, melihat tabel di atas nilai korelasi antara keduanya yaitu sebesar 0.0143 , nilai tersebut mengindikasikan tidak terdapatnya hubungan antara komunikator sebagai penyampai berita dengan pengetahuan mahasiswa terhadap pemberitaan di media massa, sehingga siapa pun penyampai beritanya, dari mana pun medianya tidak akan berpengaruh pada pengetahuan mahasiswa yang didapatkannya dari pemberitaan yang mereka baca atau akses. Tidak jauh berbeda hasil korelasi antara komunikator dengan perhatian memperlihatkan tidak adanya hubungan antara keduanya dilihat dari nilai korelasi sebesar 0.121, dari hasil tersebut dapat dikatakan bahwa siapa pun dan dari mana pun asal berita yang diberitakan di media massa, ketika mahasiswa membandingkan media tidak akan mempengaruhi perhatian mereka terhadap pemberitaan yang ada pada media massa. Dapat dikatakan pula bahwa kepercayaan mahasiswa terhadap pemberitaan di media massa tidak melihat dari siapa dan dari mana asal berita yang menjadi pemberitaan, mereka akan tetap membaca berita tersebut dari mana pun asalnya. Sedangkan untuk hubungan antara komunikator dengan penafsiran dengan nilai koefisien korelasi sebesar 0.143 memperlihatkan tidak ada hubungan antara kedua indikator tersebut, sehingga siapa pun penyampai beritanya tidak terdapat hubungan dengan penafsiran mahasiswa mengenai pemberitaan yang terdapat di media massa.

Analisis hubungan antara jumlah berita dengan pengetahuan, jumlah berita dengan perhatian dan jumlah berita dengan penafsiran juga dapat dilihat pada Tabel 2. pada tabel di atas memperlihatkan nilai koefisien korelasi antara jumlah berita dengan pengetahuan sebesar 0.235, dengan nilai signifikansi sebesar 0.006, dari hasil tersebut ditemukan bahwa terdapat hubungan yang nyata dan sangat signifikan antara jumlah berita dengan pengetahuan mahasiswa dengan arah 
hubungan searah atau positif, simpulan dari hasil korelasi kedua indikator tersebut adalah apabila semakin banyak jumlah berita yang dikonsumsi, dibaca maupun diakses di media massa maka semakin banyak pula pengetahuan yang didapat mahasiswa dari pemberitaan yang ada di media massa. Semakin banyak jumlah berita yang dibandingkan oleh mahasiswa akan semakin tinggi pula pengetahuan sehingga menyebabkan semakin tinggi kepercayaan mahasiswa terhadap pemberitaan di media massa yang ada. Sedangkan untuk hasil korelasi antara jumlah berita dengan perhatian memiliki nilai korelasi sebesar 0.091, dengan hasil korelasi tersebut didapati bahwa tidak terdapat hubungan antara Jumlah berita dengan perhatian mahasiswa dalam pemberitaan di media massa. Berbeda dengan hasil uji korelasi yang didapatkan antara jumlah berita dengan penafsiran yang memiliki nilai koefisien korelasi sebesar 0.182 dan nilai signifikansi sebesar 0.036, berdasarkan data tersebut maka hasil dari analisis tersebut adalah terdapatnya hubungan yang nyata dan signifikan antara jumlah berita dengan penafsiran dengan arah hubungan positif atau searah, dilihat dari arah hubungan tersebut maka dikatakan semakin banyak jumlah berita yang dibaca dan diakses oleh mahasiswa dan semakin banyak mereka membandingkan media dari berita tersebut maka akan semakin tinggi penafsiran mahasiswa terhadap isi pemberitaan yang ada di media tersebut yang dapat menyebabkan tingginya kepercayaan mahasiswa pada pemberitaan yang ada.

\section{Simpulan}

Terdapat beberapa kesimpulan dalam penelitian ini. Karakteristik khalayak di media massa dalam penelitian ini adalah mahasiswa yang didominasi oleh kalangan perempuan dengan perbandingan 61,2 persen dengan 38,8 persen. Umumnya mereka (61,9 persen) berusia antara 19 hingga 21 tahun. Daya beli atau uang saku mereka perbulan rata-rata senilai Rp. 500.000-1.000.000 dengan jumlah 49,3 persen. Mahasiswa yang menjadi responden dalam penelitian ini didominasi oleh mahasiswa dari tingkat 4 atau mahasiswa yang berkuliah di antara semester 7 dan 8, yakni sejumlah 50 persen. Mereka umumnya $(69,4$ persen) mempunyai indeks prestasi kumulatif (IPK) 4.

Kebiasaan membandingkan informasi di media massa pada khalayak. Pada sisi kebiasaan khalayak dalam membandingkan informasi di media massa, umumnya menyatakan setuju (67,9 persen) untuk membaca atau menyimak berita secara detil. Oleh sebab itu, mereka tidak merasa cukup hanya tahu saja, melainkan membaca atau menyimak berita secara menyeluruh. Selain itu, dalam menerima informasi, khalayak selalu mencari informasi yang sama di beberapa media yang berbeda. Namun, jumlah berita yang dibandingkan tidak terlalu banyak, yakni tidak lebih dari lima media, artinya antara 1 hingga 4 media saja yang dijadikan rujukan untuk membandingkan berita. Pada sisi komunikator atau penyampai berita, khalayak menyatakan setuju sebanyak 63,4 persen memerhatikan nama media.

Tingkat kepercayaan khalayak terhadap pemberitaan di media massa. Khalayak menyatakan setuju (76,9 persen) bahwa mereka mengetahui informasiinformasi baru dari media massa. Dengan menerima informasi dari media massa, 
responden bisa menambah wawasan terkait informasi-informasi yang ditampilkan di media massa. Di sisi lain, semakin mereka menerima banyak informasi dari media massa, responden memahami jika berita-berita yang ditampilkan di media massa tidak selalu objektif, beberapa diantaranya menguntungkan pihak-pihak tertentu. Oleh sebab itu, responden merasa perlu untuk mengetahui berita yang sama di media massa yang berbeda. Sebanyak 54,4 persen menyatakan setuju bahwa responden lebih memercayai informasi yang disampaikan oleh media massa daripada media sosial.

Relasi kepercayaan khalayak terhadap pemberitaan di media massa dengan budaya membandingkan informasi dianalisis melalui hubungan antara variabel $\mathrm{X}$ dan Y. Variabel-variabel tersebut diwakili oleh indikator sebagai berikut.

Pada esensi berita dengan pengetahuan terdapat hubungan yang nyata dan signifikan dengan arah hubungan yang positif atau searah. Esesnsi berita dengan perhatian mahasiswa terhadap pemberitaan di media massa terdapat hubungan yang nyata dan signifikan dengan arah hubungan yang positif. Esensi berita dengan penafsiran mahasiswa terdapat hubungan yang nyata dan signifikan dengan arah yang positif.

Komunikator atau penyampai berita dengan pengetahuan mahasiswa tidak terdapat hubungan, artinya responden tidak peduli dengan indentitas sumber informasi yang mereka terima. Komunikator dengan perhatian juga tidak terdapat hubungan. Komunikator dengan penafsiran juga tidak menunjukkan adanya hubungan.

Jumlah berita dengan pengetahuan terdapat hubungan yang nyata dan sangat signifikan dengan arah hubungan yang searah atau positif. Antara jumlah berita dengan perhatian mahasiswa dalam pemberitaan di media massa tidak terdapat hubungan. Sementara antara jumlah berita dengan penafsiran terdapat hubungan yang nyata dan signifikan dengan arah hubungan yang positif.

\section{Ucapan Terima Kasih}

Penulis mengucapkan terima kasih kepada pihak-pihak yang telah memberikan dukungan dalam menyelesaikan artikel ini, diantaranya: (1) Program Studi Ilmu Komunikasi, Fakultas Ilmu Sosial dan Ilmu Budaya, Universitas Pakuan, (2) Kementerian Riset, Teknologi, dan Pendidikan Tinggi Republik Indonesia, (3) Jurnal Komunikasi Universitas Tarumanagara.

\section{Daftar Pustaka}

Carrascosa, Juan Miguel, Ruben Cuevas, Roberto Gonzalez, Arturo Azcorra dan David Garcia. (2015). Quantifying the Economic and Cultural Biases of Social Media through Trending Topics. PLOS ONE, DOI; 10.1371/journal.pone.0134407

Kemenristek Dikti. (n.d.). www.forlap.dikti.go.id-

KPI. (2014, Juni 10). Pemberitaan Tidak Netral, KPI Pusat Tegur Metro TV dan

TV One. Desember 23, 2016. http://www.kpi.go.id/index.php/lihat- 
Feri Ferdinan Alamsyah, Diana Amaliasari, Imani Satriani : Relasi Tingkat Kepercayaan Khalayak Terhadap Pemberitaan di Media Massa dengan Budaya Membandingkan Informasi

terkini/38-dalam-negeri/32106-pemberitaan-tidak-netral-kpi-pusat-tegurmetro-TV-dan-TV-one

Kriyantono, Rachmat. (2012). Teknis Praktis Riset Komunikasi, Jakarta: Kencana Prenada Media.

McQuail, Denis, (2012). Teori Komunikasi Massa, Salemba Humanika, Jakarta.

Purnomo, Wayan Agus. (2014, Juni 02). Memihak Capres, KPI Tegur Lima Stasiun. Tempo Online. Desember 23, 2016. TVhttp://www.tempo.co/read/news/2014/06/02/269581863/memihakcapres-kpi-tegur-lima-stasiun-TV

Sari, Wulan Purnama. (2018) Analisis Wacana Kritis Kasus Penyerangan Terhadap Jemaah Ahmadiyah di Cikeusik. Jurnal Komunikasi, Volume 10 No 1.

$\mathrm{Hal}$ 87-94. https://journal.untar.ac.id/index.php/komunikasi/article/view/1507/1274

Sugiyono, (2016), Metode Penelitian Kuantitatif Kualitatif dan $R \& D$, alfabeta, Jakarta. 